\title{
Using Molecular Visualization as a Tool for Culturally Competent and Culturally Relevant Teaching: A Guided-Inquiry Biochemistry Activity
}

\author{
Pumtiwitt McCarthy \\ Department of Chemistry \\ Morgan State University \\ Baltimore, MD \\ Pumtiwitt.McCarthy@morgan.edu
}

\author{
Richard Williams \\ Department of Chemistry \\ Morgan State University \\ Baltimore, MD \\ rjwilmz3@gmail.com
}

\author{
Cleo Hughes-Darden et al. ${ }^{1}$ \\ Department of Biology \\ Morgan State University \\ Baltimore, MD \\ Cleo.HughesDarden@morgan.edu
}

\begin{abstract}
The central dogma is a key foundational concept in biochemistry. The idea that DNA mutations cause change at the protein level can be abstract for students. To provide a real-world example of the effect of mutation on protein function, a molecular visualization module was developed and incorporated into two biochemistry courses. This inquiry-based activity explored the molecular basis and cultural relevance of sickle cell anemia. Hemoglobin structural changes from the disease were examined. Participants used free tools including NCBI, RCSB PDB, LALIGN and Swiss PDB DeepView protein visualization software from EXPASY. This module was an active, engaging exercise which exposed students to protein visualization and increased cultural awareness.
\end{abstract}

\section{Keywords}

Biochemistry, Computer-Based Learning, InquiryBased/Discovery Learning, Internet/Web-Based Learning, Proteins/Peptides, Underrepresented Minorities, CulturallyRelevant Pedagogy

\section{INTRODUCTION}

Effective teaching of biochemistry often uses computational tools for students to visualize and analyze macromolecular structure [1, 2]. Numerous science education articles describe addition of bioinformatics to the chemistry/biochemistry curriculum [3]. Many exercises use free stand-alone or web-based tools [4] making incorporation of bioinformatics achievable. Students used bioinformatics to investigate multiple topics such as drug design [5, $6,7,8,9]$, visualization of protein structure $[10,11,12,13,14]$, homology modeling $[15,16,17]$, genomics/proteomics $[18,19]$ and genetic diseases [20]. The work described here is distinct because students use bioinformatics to investigate a genetic disease and explores the racial disproportionality of this disease. The goal of this activity was to provide students an engaging experience in protein visualization in a culturally relevant way.

Permission to make digital or hard copies of all or part of this work for personal or classroom use is granted without fee provided that copies are not made or distributed for profit or commercial advantage and that copies bear this notice and the full citation on the first page. To copy otherwise, or republish, to post on servers or to redistribute to lists, requires prior specific permission and/or a fee. Copyright CJOCSE, a supported publication of the Shodor Education Foundation Inc.
The term culturally relevant or culturally responsive pedagogy was first described over twenty years ago [21, 22]. In short, this describes a teaching approach that embraces students' different cultural perspectives to further the learning experience. One aspect of this pedagogy is cultural competence. Culturally competent pedagogy allows a teacher to impart knowledge that allows students' to appreciate their own culture and learn about the culture of others [23]. Sickle cell anemia afflicts African-Americans disproportionately. This activity provides an opportunity for a diverse set of students to research the epidemiology of the disease thereby increasing cultural awareness [24].

Genetic diseases arise from changes in DNA which leads to changes at the protein level [25]. Sickle cell anemia is caused by a point mutation in the gene message encoding hemoglobin [26]. The most prevalent mutation is a change of glutamic acid to valine in the beta subunit. Hydrophobic "sticky" patches are produced that associate with the beta subunit of other hemoglobin molecules [27]. One result of this aggregation is a decrease in iron binding and fibril formation leading to sickle-shaped red blood cells [28]. The DNA, mRNA and amino acid sequence of both types of hemoglobin are known. This activity uses free bioinformatics software and tools (Table 1) to increase student engagement with computational analysis and cultural awareness.

\section{ACTIVITY INFORMATION}

\subsection{Software Used}

Freely available software and tools were used in this activity. These are described in Table 1.

\subsection{Learning Goals}

There are five student learning goals each with specific outcomes. Learning Goal 1. Students will understand the relationship between DNA, RNA and protein sequence. Outcomes from Goal 1. If given an RNA sequence, students should be able to: a) derive the original strands of DNA; b) manually translate into amino acid sequence; use bioinformatic tools to translate into amino acid sequence. Learning Goal 2. Students will understand the effects of amino acid change on protein structure and function. Outcomes from Goal 2. Students should be able to: a) compare two amino acid sequences; b) classify and predict the severity of amino acid substitutions based on the chemical properties of amino acids; c) to highlight and label amino acids at both termini of a protein. Learning Goal 3. Students will understand how to use molecular visualization software to display and modify protein structures.

\footnotetext{
${ }^{1}$ Additional authors under "Author List"
} 
Outcomes from Goal 3. Students should be able to: a) highlight and label amino acids that interact with a ligand during binding; $b$ ) to report the racial incidence of sickle cell anemia. Learning Goal 4. Students will understand the cultural relevance of sickle cell anemia. Outcomes from Goal 4. Students should be able to: report the global incidence of sickle cell anemia. Summative assessments were used for each outcome with specific problems within the assignment.

Table 1. Software and tools used in activity $[29,30,31]$

\begin{tabular}{|c|c|c|c|}
\hline Name & Provided by & Address & Function \\
\hline NCBI & $\begin{array}{l}\text { NIH National } \\
\text { Library of } \\
\text { Medicine }\end{array}$ & $\begin{array}{l}\text { http:/www.ncbi.nl } \\
\text { m.nih.gov }\end{array}$ & $\begin{array}{c}\text {-Provides } \\
\text { access to } \\
\text { biomedical } \\
\text { and genomic } \\
\text { data }\end{array}$ \\
\hline $\begin{array}{l}\text { RCSB } \\
\text { PDB }\end{array}$ & $\begin{array}{l}\text { The Research } \\
\text { Collaboratory } \\
\text { for Structural } \\
\text { Bioinformatics }\end{array}$ & $\begin{array}{l}\text { http://www.rcsb.or } \\
\text { g/pdb/home/home. } \\
\text { do }\end{array}$ & $\begin{array}{c}\text {-Repository of } \\
\text { protein } \\
\text { structural data }\end{array}$ \\
\hline LALIGN & $\begin{array}{l}\text { ExPASy SIB } \\
\text { Bioinformatics } \\
\text { Resource Portal }\end{array}$ & $\begin{array}{c}\text { http://embnet.vital } \\
- \\
\text { it.ch/software/LA } \\
\text { LIGN_form. } \\
\text { html }\end{array}$ & $\begin{array}{l}\text {-Aligns two } \\
\text { sequences to } \\
\text { determine } \\
\text { matching } \\
\text { segments }\end{array}$ \\
\hline DeepView & $\begin{array}{c}\text { ExPASy SIB } \\
\text { Bioinformatics } \\
\text { Resource Portal }\end{array}$ & $\begin{array}{l}\text { http://spdbv.vital- } \\
\text { it.ch/refs.html }\end{array}$ & $\begin{array}{l}\text {-Protein } \\
\text { visualization } \\
\text { software }\end{array}$ \\
\hline Translate & $\begin{array}{l}\text { ExPASy SIB } \\
\text { Bioinformatics } \\
\text { Resource Portal }\end{array}$ & $\begin{array}{l}\text { https://web.expasy } \\
\text {.org/translate/ }\end{array}$ & $\begin{array}{l}\text {-Translates } \\
\text { nucleotide } \\
\text { sequence to } \\
\text { protein } \\
\text { sequence }\end{array}$ \\
\hline $\begin{array}{l}\text { Google } \\
\text { Docs }\end{array}$ & Google & $\begin{array}{l}\text { http:/docs.google. } \\
\text { com }\end{array}$ & $\begin{array}{l}\text {-Web-based } \\
\text { word } \\
\text { processing } \\
\text { tool }\end{array}$ \\
\hline
\end{tabular}

\subsection{Tenets of Culturally Sensitive Teaching} Adopted

This activity was developed as one part of a wider inter-department goal of increasing culturally sensitive teaching in STEM courses [32]. A cohort of faculty from the departments of Mathematics, Computer Science, Chemistry, Biology, Physics, Industrial Engineering and Information Sciences and Systems developed five tenets for culturally-sensitive pedagogy in our courses. These were: 1) to incorporate physical and hands on activities in instructional practice, 2) to incorporate physical and hands on activities in instructional activities, 3) to become conscious of biased judgements about students based on limited perceptions of them and be willing to change these perceptions, 4) to have student apprenticeships that foster empowered learning communities and 5) to use students' lived experiences as content for course content and activities.

\subsection{Activity Information}

\subsubsection{Participants and Materials}

Students in CHEM 202 Biochemistry for Health Majors are second-year undergraduate Medical Technology majors and upperdivision undergraduate Nutrition majors. Students in CHEM 304 Biochemistry are upper-division level Chemistry and Biology majors. These students anticipate entering graduate or medical school after graduation. Activities were performed during consecutive laboratory periods. CHEM 202 has $2 \mathrm{hr} 50 \mathrm{~min}$ allotted for lab each week while CHEM 304 has $3 \mathrm{hr} 50$ min allotted.
Ten laptop computers were provided by the Chemistry Department. Groups of 2-4 students performed the activity. One computer was provided per group.

\subsubsection{Pre-laboratory Activities}

Students were assigned a pre-lab activity about the Protein Data Bank (PDB) and hemoglobin structure and function. A YouTube video [32a] about the PDB was made available on the online course management system. An article from the Molecule of the Month on the PDB website [33] about hemoglobin and sickle-cell anemia was assigned and students answered instructor-supplied questions.

\subsubsection{Overview of Laboratory Activity}

Modules were performed over two course laboratory periods. In the first week, students learned crystal structure basics and how to use computer software to visualize them. Targeted questions discuss cultural relevance and impact. The assignment called for students to download the crystal structure of normal hemoglobin from the PDB (PDB ID: 1hho [34]) and visualize its structure in Swiss DeepView. Next, they examined the secondary structure elements present in the protein. Students identified and labeled the N- and Ctermini and the histidine residues that coordinate the heme group. The amino acid position that will be changed in the sickle cell variant was also identified and labeled by students. At the end of the exercise students are asked to answer questions related to rate of occurrence, racial incidence, symptoms and cure for the disease.

In the second week, students compare the 3-dimensional structure of sickle cell hemoglobin (PDB ID: 2hbs [35], Figure 1) to normal.

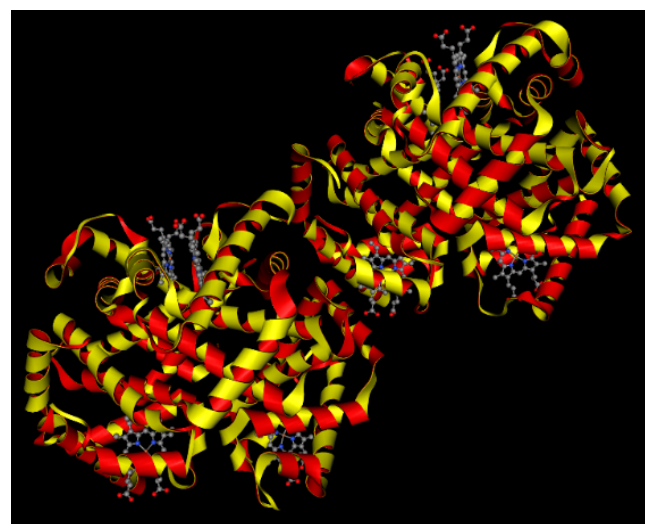

Figure 1. Crystal Structure of Sickle Cell Hemoglobin (2hbs)

They also engage with the central dogma by analyzing the DNA, RNA and amino acid sequence manually and with online bioinformatics software. As before, students use Swiss DeepView to label pertinent histidine residues. Students are also asked to discuss changes in the crystal structure between the normal and sickle hemoglobin. A portion of mRNA from wild type and sickle cell hemoglobin are given to students to translate into amino acid sequence manually. They also derive the original DNA sequence for both variants of hemoglobin. Next, the entire mRNA sequence of both types of hemoglobin is provided and online tool is used to translate sequences. LALIGN was used to compare similarity. All answers went into a Google document shared with group members and the instructor. 


\section{RESULTS AND DISCUSSSION 3.1 Impact of Activity on Student Engagement and Cultural Awareness}

This activity was developed over two summers and implemented in Spring 2016 for CHEM 202. It was used in both courses the following academic year. Over 70 students have been exposed to this activity over this time. This activity is student-centered with very little instructor interaction. The instructor offers a brief introduction to the activity and the students begin following the step-by-step instructions for each week. When questions arise, the instructor clarifies for students. They also have access to the internet during this time. This activity was successful in engaging students. During implementation of the module in CHEM 202 in Spring 2016, a team of evaluators observed the class and scored the activity on the level of student engagement and use of computational tools. The scale runs from 1 (lowest) to 7 (highest). Evaluators found that the module scored high on all aspects. Specifically, the module "incorporated engaging team-based, real world projects" (score $=7$ ), "used computational tools for modeling and simulations" (score $=7$ ), students "understood why they were using computational tools" (score $=6)$ and "student's interest in the class" ( score $=7$ ).

Sickle cell anemia was chosen for its cultural relevance and because students were introduced to it earlier in the semester. Morgan State University is becoming increasingly diverse. Morgan State University is a Historically Black College or University (HBCU) located in Baltimore, MD. In 2016-2017, 22 participants identified themselves as African-American (64\%), 6 as Caucasian (18\%), 5 were international $(15 \%)$, and 1 was multiracial $(3 \%)$. Therefore, many cultural backgrounds learned about this disease and its incidence.

\subsection{Alignment with Developed Tenets of Culturally Sensitive Teaching}

This exercise was developed keeping five main culturally-sensitive goals in mind. These were 1) to incorporate physical and hands on activities in instructional practice, 2) to incorporate more studentled discussions and teaching opportunities in class, 3 ) to becoming conscious of biased judgments about students based on limited perceptions of them and be willing to change these perceptions, 4) to have student apprenticeships that foster empowered learning communities and 5) to use students' lived experiences as content for course content and activities. All five of these goals were achieved. This was primarily a student-led protein visualization project. There was a very brief introduction to the students by the instructor about what they will be doing, but the students discussed within their group and across groups how best to complete assignments (Tenets 1, 2, and 4). All students were treated in an equitable fashion and resources were made available to all students (Tenet 3). During the activity, one student was also able to offer a personal perspective as they had a family member that has the disease (Tenet 5).

\subsection{Activity Outcomes}

At implementation of this activity, students have already learned about the different levels of protein structure and are starting to learn the details of the central dogma. Hemoglobin and sickle cell hemoglobin had been discussed. Relevant concepts such as quaternary structure, protein-ligand binding and allosterism had also been discussed. This activity was designed to integrate early course material with new material that they are learning.
Learning goals and outcomes are described in Section 2.2. In the Bloom's taxonomy hierarchy [36], these integrated questions range from lower level "knowledge" to higher level "evaluation" and "synthesis". One example of an integrated question asks students to look at the amino acid sequences of the proteins and label the $\mathrm{N}$ and C-termini of each subunit and determine whether the structure is the oxygen-bound form. Students must recall their knowledge of amino acid codes, protein directionality, and hemoglobin subunits. An example of an "evaluation" type is when students are asked to translate both types of hemoglobin into amino acid sequence. During alignment of the two sequences students must determine which alignments are correct and the number of sequence positions where they differ. Overall, the module successfully introduced students to protein visualization, reinforced knowledge of the central dogma and increased cultural awareness.

\section{CONCLUSIONS AND FUTURE WORK}

Genetic diseases can serve as tractable examples of the central dogma's importance. A mutation in sickle cell anemia leads to hemoglobin structural changes that students were able to investigate using free resources. This module explored the molecular basis and cultural relevance of sickle cell anemia to help increase cultural competency. Future versions of this module will better assess student engagement with protein visualization.

Student handouts with step-by-step instructions and laboratory questions, Student pre-lab activity; mRNA sequence of normal and sickle-cell hemoglobin chain $\mathrm{A}$, and example student data are available from the authors by email request to Pumtiwitt.McCarthy@morgan.edu.

\section{AUTHOR LIST}

Additional authors in order are: Roni Ellington ${ }^{2}$, Paminas Mayaka ${ }^{2}$, Monica Jackson ${ }^{3}$ and Asamoah Nkwanta ${ }^{4}$

${ }^{2}$ Advanced Studies, Leadership, and Policy, Morgan State University, 1700 East Cold Spring Lane, Baltimore, MD 21251, ${ }^{3}$ Department of Mathematics and Statistics, American University, 4400 Massachusetts Avenue, NW, Washington, DC 20016, ${ }^{4}$ Department of Mathematics, Morgan State University.

\section{ACKNOWLEDGMENTS}

The authors were partially supported by the Association of American Colleges \& Universities, Project Kaleidoscope (PKAL) through a Teaching to Increase Diversity and Equity in STEM (TIDES) grant. None of the authors have a financial, personal, or professional conflict of interest related to this work.

\section{REFERENCES}

[1] Jaswal, S. S., O'Hara, P. B., Williamson, P. L. and Springer, A. L. Teaching structure: Student use of software tools for understanding macromolecular structure in an undergraduate biochemistry course. Biochemistry and Molecular Biology Education, 41, 5 (2013), 351-359.

[2] Schonborn, K. J. and Anderson, T. R. The importance of visual literacy in the education of biochemists*. Biochemistry and molecular biology education : a bimonthly publication of the International Union of Biochemistry and Molecular Biology, 34, 2 (Mar 2006), 94-102. 
[3] Magana, A. J., Taleyarkhan, M., Alvarado, D. R., Kane, M., Springer, J. and Clase, K. A Survey of Scholarly Literature Describing the Field of Bioinformatics Education and Bioinformatics Educational Research. CBE life sciences education, 13, 4 (Winter 2014), 607-623.

[4] Craig, P. A., Michel, L. V. and Bateman, R. C. A survey of educational uses of molecular visualization freeware. Biochemistry and Molecular Biology Education, 41, 3 (2013), 193-205.

[5] Hayes, J. M. An Integrated Visualization and Basic Molecular Modeling Laboratory for First-Year Undergraduate Medicinal Chemistry. Journal of Chemical Education, 91, 6 (2014/06/10 2014), 919-923.

[6] Peterson, R. R. and Cox, J. R. Integrating Computational Chemistry into a Project-Oriented Biochemistry Laboratory Experience: A New Twist on the Lysozyme Experiment. Journal of Chemical Education, 78, 11 (2001/11/01 2001), 1551.

[7] Rodrigues, R. P., Andrade, S. F., Mantoani, S. P., EiflerLima, V. L., Silva, V. B. and Kawano, D. F. Using Free Computational Resources To Illustrate the Drug Design Process in an Undergraduate Medicinal Chemistry Course. Journal of Chemical Education, 92, 5 (2015/05/12 2015), 827-835.

[8] Swope, N. K., Fryfogle, P. J. and Sivy, T. L. Detection of the cp4 epsps Gene in Maize Line NK603 and Comparison of Related Protein Structures: An Advanced Undergraduate Experiment. Journal of Chemical Education, 92, 7 (2015/07/14 2015), 1229-1232.

[9] Tsai, C. S. Using Computer Applications and Online Resources To Teach and Learn Pharmaceutical Chemistry. Journal of Chemical Education, 84, 12 (2007/12/01 2007), 2019.

[10] Cox, J. R. Teaching Noncovalent Interactions in the Biochemistry Curriculum through Molecular Visualization: The Search for pi Interactions. Journal of Chemical Education, 77, 11 (2000/11/01 2000), 1424.

[11] Lowery, M. S. and Plesniak, L. A. Some Like It Cold: A Computer-Based Laboratory Introduction to Sequence and Tertiary Structure Comparison of Cold-Adapted Lactate Dehydrogenases Using Bioinformatics Tools. Journal of Chemical Education, 80, 11 (2003/11/01 2003), 1300.

[12] McLaughlin, K. J. Understanding Structure: A ComputerBased Macromolecular Biochemistry Lab Activity. Journal of Chemical Education, 94, 7 (2017/07/11 2017), 903-906.

[13] Rowe, L. Green Fluorescent Protein-Focused Bioinformatics Laboratory Experiment Suitable for Undergraduates in Biochemistry Courses. Journal of Chemical Education, 94, 5 (2017/05/09 2017), 650-655.

[14] Ship, N. J. and Zamble, D. B. Analyzing the 3D Structure of Human Carbonic Anhydrase II and Its Mutants Using Deep View and the Protein Data Bank. Journal of Chemical Education, 82, 12 (2005/12/01 2005), 1805.

[15] León, D., Uridil, S. and Miranda, J. Structural Analysis and Modeling of Proteins on the Web: An Investigation for Biochemistry Undergraduates. Journal of Chemical Education, 75, 6 (1998/06/01 1998), 731.
[16] Petrović, D. and Zlatović, M. Modeling Human Serum Albumin Tertiary Structure To Teach Upper-Division Chemistry Students Bioinformatics and Homology Modeling Basics. Journal of Chemical Education, 92, 7 (2015/07/14 2015), 1233-1237.

[17] Tsai, C. S. A Computer-Assisted Tutorial on Protein Structure. Journal of Chemical Education, 78, 6 (2001/06/01 2001), 837.

[18] Ditty, J. L., Kvaal, C. A., Goodner, B., Freyermuth, S. K., Bailey, C., Britton, R. A., Gordon, S. G., Heinhorst, S., Reed, K., Xu, Z., Sanders-Lorenz, E. R., Axen, S., Kim, E., Johns, M., Scott, K. and Kerfeld, C. A. Incorporating genomics and bioinformatics across the life sciences curriculum. PLoS biology, 8, 8 (Aug 10 2010), e1000448.

[19] Kossida, S., Tahri, N. and Daizadeh, I. Bioinformatics by Example: From Sequence to Target. Journal of Chemical Education, 79, 12 (2002/12/01 2002), 1480.

[20] Schneider, T. L. and Linton, B. R. Introduction to Protein Structure through Genetic Diseases. Journal of Chemical Education, 85, 5 (2008/05/01 2008), 662.

[21] Ladson-Billings, G. Reading between the Lines and beyond the Pages: A Culturally Relevant Approach to Literacy Teaching. Theory Into Practice, 31, 4 (1992), 312-320.

[22] Ladson-Billings, G. Toward a Theory of Culturally Relevant Pedagogy. American Educational Research Journal, 32, 3 (1995), 465-491.

[23] Ladson-Billings, G. Culturally Relevant Pedagogy 2.0: a.k.a. the Remix. Harvard Educational Review, 84, 1 (2014), 7484.

[24] Ojodu, J., Hulihan, M. M., Pope, S. N. and Grant, A. M. Incidence of sickle cell trait--United States, 2010. $M M W R$. Morbidity and mortality weekly report, 63, 49 (Dec 12 2014), 1155-1158.

[25] Crick, F. Central Dogma of Molecular Biology. Nature, 227, 5258 (08/08/print 1970), 561-563.

[26] Piel, F. B., Steinberg, M. H. and Rees, D. C. Sickle Cell Disease. The New England journal of medicine, 376, 16 (Apr 20 2017), 1561-1573.

[27] Chou, P. Y. $\beta$-Sheet aggregation proposed in sickle cell hemoglobin. Biochemical and Biophysical Research Communications, 61, 1 (1974/11/06/ 1974), 87-94.

[28] Finch, J. T., Perutz, M. F., Bertles, J. F. and Dobler, J. Structure of sickled erythrocytes and of sickle-cell hemoglobin fibers. Proceedings of the National Academy of Sciences of the United States of America, 70, 3 (Mar 1973), 718-722.

[29] Artimo, P., Jonnalagedda, M., Arnold, K., Baratin, D., Csardi, G., de Castro, E., Duvaud, S., Flegel, V., Fortier, A., Gasteiger, E., Grosdidier, A., Hernandez, C., Ioannidis, V., Kuznetsov, D., Liechti, R., Moretti, S., Mostaguir, K., Redaschi, N., Rossier, G., Xenarios, I. and Stockinger, H. ExPASy: SIB bioinformatics resource portal. Nucleic Acids Res, 40, Web Server issue (Jul 2012), W597-603. 
[30] Berman, H. M., Westbrook, J., Feng, Z., Gilliland, G., Bhat, T. N., Weissig, H., Shindyalov, I. N. and Bourne, P. E. The Protein Data Bank. Nucleic Acids Research, 28, 1 (2000), 235-242.

[31] Guex, N. and Peitsch, M. C. SWISS-MODEL and the SwissPdbViewer: an environment for comparative protein modeling. Electrophoresis, 18, 15 (Dec 1997), 2714-2723.

[32] Hughes-Darden, C.; Ellington, R.M.; Zaveri, J.; Bapna, S.; Akil, L.; Hargett, S.; Bhattacharya, P.; Emdad, A.; Nkwanta, N. Interventions Addressing Recruitment and Retention of Underrepresented Minority Groups in Undergraduate STEM Disciplines. Emerald Publishing, Bingley, UK, 2019.[32a] [Alchemigus]. (2014, June 21). PDB RCSB Introduction/Tutorial [Video File]. Retrieved from: https://youtu.be/_ok64nYRiCY
[33] Goodsell, D. S., Dutta, S., Zardecki, C., Voigt, M., Berman, H. M. and Burley, S. K. The RCSB PDB "Molecule of the Month": Inspiring a Molecular View of Biology. PLoS biology, 13, 5 (May 2015), e1002140.

[34] Shaanan, B. Structure of human oxyhaemoglobin at $2.1 \mathrm{~A}$ resolution. Journal of molecular biology, 171, 1 (Nov 25 1983), 31-59.

[35] Harrington, D. J., Adachi, K. and Royer, W. E., Jr. The high resolution crystal structure of deoxyhemoglobin S. Journal of molecular biology, 272, 3 (Sep 26 1997), 398-407.

[36] Crowe, A., Dirks, C. and Wenderoth, M. P. Biology in bloom: implementing Bloom's Taxonomy to enhance student learning in biology. CBE life sciences education, 7, 4 (Winter 2008), 368-381. 